\title{
Enhancing Education for Sustainable Development in Environmental University Programmes: A Co-Creation Approach
}

\author{
Maria Rosario Perello-Marín ${ }^{1,+}$, Gabriela Ribes-Giner ${ }^{1,+}$ and Odette Pantoja Díaz ${ }^{2, *,+}$ \\ 1 Faculty of Business Administration and Management, Universitat Politècnica de València, Camino de Vera, \\ s/n 46022 Valencia, Spain; rperell@upvnet.upv.es (M.R.P.-M.); gabrigi@omp.upv.es (G.R.-G.) \\ 2 Escuela Politécnica Nacional, Ladrón de Guevara E11-253, 170517 Quito, Ecuador \\ * Correspondence: odettepantoja1980@gmail.com; Tel.: +593-9-8417-0055 \\ + These first three authors contributed equally to this work.
}

Received: 24 October 2017; Accepted: 8 January 2018; Published: 11 January 2018

\begin{abstract}
The purpose of this study is to analyse co-creation approach as a strategy at HE as a prerequisite for a successful implementation of sustainable development (HESD), while considering student collaboration in university processes. A questionnaire was handed in to 395 undergraduate environmental students from twelve Ecuadorian universities to test a structural equation model that included four variables-participation, co-creation, satisfaction, and trust. It is worth noting that these topics are increasingly relevant in competitive and innovative universities when promoting management in HESD. The results verify that student participation, as one of the key ESD skills, has a significant and positive influence on co-creation as a generator of student satisfaction and trust, especially in this context. Co-creation, from a higher education perspective, from the premise that students are the centre of the learning process, reinforces the education quality principles in an innovative way, and promotes the HESD perspectives.
\end{abstract}

Keywords: higher education for sustainable development; environmental engineering student; co-creation; trust; satisfaction; participation; Ecuador

\section{Introduction}

Education for Sustainable Development (ESD) was recognized in 1992 by Agenda 21 in the Earth Summit conducted in Brazil with the aim of seeking a balance between "human and economic well-being with cultural traditions and respect for the Earth's natural resources" through educational practice [1] (p. 105). Particularly, the initial goal of ESD was the incorporation of ecological, economic, and environmental aspects throughout the lifelong learning process [2]. Focusing on Higher ESD, it aims to go beyond the generation and acquisition of knowledge, being reflected on further effects and even behaviours and decisions in a future-oriented and global perspective of responsibility, by incorporating ecological, economic and environmental aspects into the whole process [3,4]. Therefore, ESD at university context seeks to implement programs that enable students to build not also skills and competences, but also attitudes and values they will need to cope with future sustainable issues [5], to ensure their commitment to fulfilling their duty to generate sustainable societies $[6,7]$.

Previous studies show ESD based on a perspective comprehending a modification of the educational paradigm of the teaching and learning process [1,8], based on a shift from classical education frameworks, to other models fostering not only knowledge transmission, but also value creation and development [5]. This educational re-orientation enhance the achievement of SD competences by the students since the learning process turns into an interdisciplinary, trans-disciplinary, problem based, and self-regulated process [5]. Therefore, some advantages of 
ESD have been seen as the generation of student competencies related to collaboration through critical thinking, decision-making based on problem solving, enhancement of communication abilities (written and oral), collaboration, conflict management, and planning $[3,5,9,10]$.

Taking into account this transformative perspective, it is necessary to redirect the resources and the relationship among the stakeholders involved in higher education institutions (HEI) [11] and to reshape teaching and learning processes based on the principles of sustainability [12]. Under this new concept, the institutions must encourage communication and dialogue on sustainable topics, reorienting them towards new strategic models. Those strategic models are important for universities due to the changing environment and teaching perspective. They need to be flexible in order to be ready to face future changes. However, despite the previous studies that have been carried out analyzing and testing other methodological approaches in order to enhance the involvement of HEI in sustainability issues, the research in this topic remains scarce, been universities "far from reorienting themselves toward sustainability" [13] (p. 66).

When considering that value co-creation in HEI is based on active connections between the institution and students through strong communication ties [14], and that students participate actively in the process of creating value in order to acquire knowledge and develop transversal skills that are necessary for their subsequent integration into the labor market [15], this piece of research presents the co-creation approach as a way to strengthen HESD [16].

Some of the communication alternatives to be developed from the co-creation perspective may be the creation of virtual channels, the use of mobile systems, to provide and receive information, the creation of spaces where students and university staff can share information, opinions and proposals. On the other hand, the concept of co-creation or co-production of knowledge at HE refers to the active students' commitment and engagement throughout the learning process, which is also a premise for a successful process. This new approach is recognized as a source of student retention [17], not only increasing student trust, enhancing satisfaction and quality levels [18], reducing the gap between students and HEI, but also increasing their impact on staff and faculty, and thus promoting deep learning [17] and setting the groundwork for ESD long life learning. In this sense, co-creation is seen as an approach that would help to promote ESD, since both have similar principles and premises.

It is important to highlight that HESD application has significant differences depending on each national context, due to the political and cultural reality of each country. The teaching and learning methodology applied varies according to country particularities, differing from each other. To date, HESD has been mainly studied in developed regions [19]. Within this piece of research, the Ecuadorian context has been analysed as an example of a developing country, a context that has not yet been widely studied. On the other hand, although ESD is a multidisciplinary approach, and it aims to embed their principles and values thoroughly in order to achieve a sustainable society, more equitable, it can be applied to many other disciplines. Within this study, a specific undergraduate program has been selected to be studied. It does not have to be the most representative one, but it is a first step to establish the foundations of the relationship between co-creation and HESD in a developing country, which has not yet been widely studied to date.

Particularly, this study is focused particularly on environmental engineering degrees since these programmes have the greatest impact on training professionals focused on SD [20], and this fact has been proven to be necessary to be strengthen in Ecuador. In particular, in the Ecuadorian context, the development of environmental studies has been promoted in recent years. Despite the efforts made, and the change experienced in Ecuadorian education, a great deal, in terms of research, remains to be done; the lack of research addressing HESD in this context is a fact [19].

It should be noted that although co-creation has been already studied previously within a HE context, both in the postgraduate and undergraduate context [21-26], when referring to environmental programmes, previous studies present a narrower scope than the piece of research presented in this 
paper. On the one hand, they are too specific and they only address part of the issue, and, on the other hand, they study neither developing context, nor Ecuadorian context specifically in depth.

The main contribution of this research is to present co-creation as a way to promote HESD at HEI, since it promotes the development of skills and competences that are also relevant for sustainability. This paper specifically analyses environmental engineering students, however, HESD could be further applied to any other discipline. To do so, the existing links between four factors have been measured: participation, co-creation, satisfaction, and trust, within Ecuadorian HEI context, since, as it has been seen in previous studies, context may affect the definition of ESD, and also the way in which it is implemented and assessed [27]. In this way, the impact of this collaborative perspective on student behaviour is demonstrated, when considering the need to bolster research work on the impact of student involvement with regard to their attitudes and skills [28] reinforcing the HESD aspect.

This paper is structured as follows. Section 2 analyses the HESD context in Ecuadorian universities and the existing links with co-creation as a feasible approach. Section 3 comments on the proposed model, and the theoretical connections between participation, co-creation, satisfaction, and trust. Section 4 reflects the methods applied and Section 5 shows the main results obtained. Section 6 contains the discussion and main implications of these results, and finally, Section 7 shows the limitations and further research that may be necessary.

\section{Background about HESD, Ecuadorian HE and Co-Creation}

\subsection{HESD Context}

There are several areas where HEI can favourably apply ESD. One of the cornerstones affects to the development of the educational activities by designing courses with learning goals that are clearly focused upon multidisciplinary approaches to the development of sustainable societies [29]. This new approach involves a change in the existing teaching-learning structure, being now necessary to modify monodisciplinary tendencies and to enhance the collaboration among the different actors involved (staff, faculty, students, funding bodies, employers, and community) in order to obtain sustainable societies [30]. One of the most revolutionary changes required is the transition from "learning by listening" to "learning by doing", which is essential to involve students in ESD [31]. Furthermore, ESD reinforces experimental practices and an interactive learning methodology in order to enhance understanding [1].

All in all, HESD implies a paradigm change establishing a new learning perspective based on the inclusion of students in the whole process [32]. One of the key aspects is to promote active student participation with the community, or in other words, to conceive students as co-creators of knowledge, and as gatekeepers to the community and drivers of the needed change for SD [33]. As [1] (p. 107) reflect, the pedagogical transition to this new focus is based on "a general shift from teacher-centered training and instruction to learner-centered learning and capacity-building," broadening the dialogue, critical reflection and active collaboration. This reinforcement of communication, teamwork and student involvement allows for the development of skills, such as self-learning, problem-solving, and critical-creative thinking [34]. This mind-set trains creative and independent individuals with a tendency for innovation, who think independently and act cooperatively [35]. In the context of HESD, [36] research on five core capabilities that are related to sustainability has been carried out. They include system thinking (related to the ability to interconnect environmental, social, and economic perspectives), anticipatory (related to the ability to analyse future sustainable implications), regulatory (related to the timely use of sustainability knowledge regulation), and finally, strategic and interpersonal competences. It has been demonstrated that the most relevant capability from all the above is the interpersonal capability, which is based on collaborations and leadership. Also, in their research, [37] comment that another important skill to be enhanced by any sustainable professional is communication, especially with the aim of assuring an effective dialogue among other non-expert 
stakeholders. These findings remark the relevance of communication and teamwork skills. Therefore, they become essential, and, hence, they need to be developed within HESD programs.

On the other hand, students' participation in learning experiences "such as voluntary, service-learning or classroom-based" increase their sustainable self-efficacy, value and affect [38] (p. 150). In this context, self-efficacy refers to students' beliefs towards their own abilities; value is related to task importance and is associated to students' reaction. When considering these main terms and findings, once again, in terms of sustainable engineering programmes, students' participation also becomes an essential requirement when developing new educational models based on active student collaboration.

As the aforementioned studies suggest, students' collaboration at HEI guarantees their success establishing commitments to learning, as well as fostering SD. Likewise, [39] analyse the main students' motivators in SD educational programmes in their research. They are: autonomy, challenge of reflection, connection with others, and self-fulfilment. Their results demonstrate the predominance of all of them, with the proviso that autonomy is only identified in the context of works in teams but not individually, reinforcing the importance of interactive learning.

By developing these student skills, HESD is training people capable of "making informed decisions that benefit themselves and others, in the present and future" [34] (p. 3) as a result of community development. In addition, [35] insist on the crucial role of HESD in the generation of those skills, necessary to place alumni in the labour market.

Environmental degrees, while they are not the only ones, strongly promote sustainable development. They are focused on developing skills in students and promoting knowledge and experience in order to solve environmental problems and seeking solutions for improving the quality of life and the environment. These programmes are focused on training students to enable proper handling and management of natural resources, positioning them in the labour market as a valuable force able to achieve sustainable development [20]. These programmes are bolstered in part due to the high impact of engineering works on the environment, being a compelling reason to reinforce sustainable education in an undergraduate context [40]. Finding solutions to improve an environment friendly live style is a priority that must be fostered in an educational context. Additionally, climate change and other sustainable development concerns are translated as an increasing demand for professionals in sustainability and environmental areas.

Despite ESD being a transversal topic to be included in different knowledge areas, it remains as a key element to be applied mainly in environmental programmes due to its very nature, as it has been shown above.

\subsection{Ecuadorian HE Perspectives}

ESD has mainly been researched in developed countries contexts. Studies that analyse this practice in developing countries have yet not been carried out, including the Latin-American region. When considering that ESD has its particularities according to each country's singularity and also to the fact that research in this region is poorly addressed, the Ecuadorian context could be an interesting area to analyse in order to explored this topic.

The current existing government in Ecuador has played a leading and ground breaking role in several areas of Ecuador (political, economic, social, educational, productive and environmental), whose transformative base is known as the National Plan for Good Living, or "Plan Nacional del Buen Vivir" (PNBV) in Spanish. This plan is a guide aiming at "the way of life that allows happiness and permanence of cultural and environmental diversity in harmony, equality, equity and solidarity" [41] (p. 14). The PNBV is applied in order to maintain and promote people's right to live in harmony with nature, with respect for their rights and in a clean and healthy environment. The plan is composed of a set of objectives, each focused on different areas (economic, cultural, social, education, politics), which are monitored to generate actual knowledge of the existing impacts on governance. Such monitoring makes the PNBV a solid management tool for decision making purposes. 
The PNBV objectives function as a stimulus of the HESD [19]. When considering this, the Council of Ecuadorian Higher Education established that, in the design and introduction of new degree programmes, universities should include actions and programmes focused on obtaining graduate profiles covering the objectives included in the PNBV [42]. This approach leads to train professionals with learning outcomes aligned with existing policies.

In this sense, objective number 7 in the PNBV aims to "guarantee the rights of nature and promote a healthy and sustainable environment, through comprehensive planning to preserve habitats, manage efficiently the resources, repair integrated systems and introduce life in real harmony with nature" [41] (p. 222). This objective is set due to the impact of productive activities in the country on the vast natural resources. Its purpose is the preservation of such great biodiversity and its sustainable use throughout the country.

Another element included in the PNBV is the educational sector. The Ecuadorian higher education system is going through a profound change, where graduates, who have the ability to find solutions to social problems, are becoming key players. Social responsibility is supported at universities, and a process reorganisation programme that places students as the centre of the learning process is being developed [43].

This situation has led Ecuadorian universities to design new degree programmes, especially in areas that are related to HESD, and, particularly, to environmental engineering, when considering the aforementioned Objective number 7 as a premise for the design and development of the graduate profile. As a result, several higher education institutions, such as the Escuela Politécnica Nacional, Universidad Politécnica Salesiana, Pontificia Universidad Católica del Ecuador, Universidad Agraria del Ecuador, Universidad de las Américas, Universidad Tecnológica Equinoccial, Universidad Estatal Amazónica, Universidad San Francisco de Quito, Universidad Técnica de Machala, Universidad Técnica de Ambato or Universidad Técnica Particular de Loja, among others, are fully focused on this objective. Within the core competencies to be acquired by graduates they have incorporated the development of skills, such as effective communication to interact with different audiences, leadership, generation and assessment of solutions, critical thinking, open-mindedness, entrepreneurial spirit, logical reasoning, and willingness to interact as a team. The aforementioned skills are core capabilities related to HESD [36,37], which are also empowered by knowledge co-creation [43].

\subsection{The Connection between HESD and Co-Creation}

One of the emerging areas included in the 4th International Conference on Higher Education for Sustainable Development "Higher Education for Sustainable Development: Moving the Agenda Forward," organized by the UNESCO Chair for Higher Education for Sustainable Development, is to focus in management education for sustainable development. Regardless of the fact that this issue has not been analysed in depth yet [16], a new approach is offered in this study, the application of co-creation as a marketing approach in order to foster the management of HESD. Student co-creation allows for stakeholders to listen and to take into account the students' voice in terms of their opinions or feelings about their institutional experience. Nowadays, this fact is a core value in an HE inclusive system [44]. Although several approaches and criteria have been already provided by scholars in an HE context, there is still lack of consensus on how to implement co-creation processes [45-48].

The fact that students play an active role by becoming co-creators is undeniable, and this has positive implications for breaking down the barriers between staff and students. Students gain skills as "critical thinkers and critical beings in the world" and acquire "more responsibility for their own learning" [49] (p. 134). This student enrolment approach ensures that the learning will be greater and encourages teaching staff to receive feedback through this dynamic exchange [50]. Therefore, they do not only gain skills, but also knowledge.

In this piece of research, co-creation in HESD is analysed, with an eye towards enhancing teaching-learning participatory processes. It is considered that an inclusive perspective, where students 
have a voice, co-create their own knowledge, and are involved in different university processes, increases, in this way, their skills and competences [17,44], and hence their further applicability.

When analysing co-creation in HE, within the different elements that make up the university (students, staff, faculty, and researchers), students were chosen as the core element of this analysis based on the fact that, within the above mentioned new teaching and learning approaches in HESD, students hold a prominent role, not just learning, but also interacting with faculty and the institutions themselves [49].

\section{The Proposed Model}

The foundations of HESD are strongly tied to the co-creation concept, and, as [35] (p. 107) state, ESD "enables all individuals to fully develop the knowledge, perspectives, values and skills necessary to take part in decisions to improve the quality of life." However, this relationship has not been developed before through a powerful mathematical model. Based on this statement, co-creation has been considered as a way to promote HESD since it promotes the development of skills and competences relevant for sustainability. In this way, the proposed model aims to encourage the growth of sustainability practices in certain academic environment, and, hence, in society, by integrating HE stakeholders, particularly students, in the university process.

Although co-creation requires the involvement of all the stakeholders, current research has only focused on the role of environmental programme students in this process and how their relationship with the university improves HESD through co-creation. When considering that student participation is a key factor in the management of HESD, the present piece of research explores its relationship with co-creation, and among co-creation and trust and satisfaction.

Once the conceptual framework of co-creation has been introduced, a co-creation model, as shown in Figure 1, is presented and analysed. This model contains the following variables: participation, co-creation, satisfaction, and trust. Participation has been seen as a relevant component to successfully implement HESD. On the other hand, satisfaction and trust are analysed as results that may enhance the SD learning outputs of the students, and hence their implication in sustainable practices in the future.

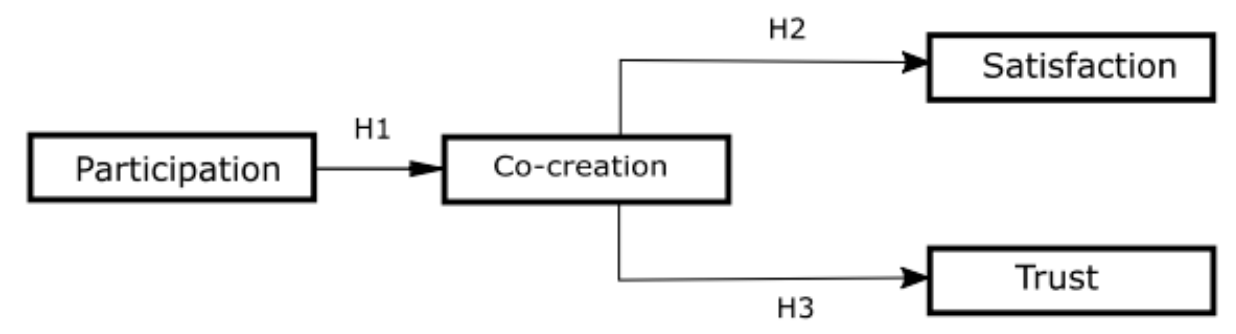

Figure 1. Proposed co-creation model.

The first variable, participation, refers to the relationship and collaboration between students and faculty [51,52]; that is, the level of student immersion in the aforementioned strategies for co-creation in HE.

Taking the concept from its foundations, co-creation addresses customer involvement from the initial idea phase for product or service development. Innovative channels should be developed to ensure that the involved parties are in sync, with success being associated with the proper performance of different actors $[14,53,54]$. Likewise, value co-creation in HE can be defined as the process of connecting and immersing students throughout the entire process of value creation. It implies a shift of perspective in HE from a value-delivery approach - "doing something to students" - to a co-creation approach-"doing something with students". Therefore, this new approach holds that HE should not simply "provide" value to students, but that students should actively participate in the process, playing an active role through direct interaction $[45,46]$. Resources, then, come not only from the 
faculty's side (as the traditional supplier), but also from the student's, resulting in resource integration in the production of HE service [55].

Moreover, previous studies, as it will be mention further, demonstrated theoretically and empirically that co-creation impacts positively on satisfaction and trust [56]. When considering these ties, the present piece of research also explores whether these links remain at the HESD context. In particular, the influence of co-creation on student behaviour in terms of sustainability attitudes reinforced by satisfaction and/or trust is analysed.

Satisfaction is related to student perception of the university's services. Increased satisfaction exerts a positive effect on student loyalty, decreasing the turnover rate, and price sensitivity; that is, the amount of students dropping out of university before they complete their degree, and their propensity to change from one institution to another, specifically for tax reasons. Furthermore, student retention increases as levels of student satisfaction increase [57]. All in all, student satisfaction is linked to an effective learning, especially in sustainability issues [58].

When addressing trust at HE, it is linked to student confidence in the institution, which includes elements of reliability and integrity [59]. Trust constitutes "a multidimensional psychological state containing interrelated emotional and cognitive elements as well as cultural meanings, beliefs and social interactions" [60] (p. 4). Student trust allows for an effective adoption and implementation of HESD at HE institutions [56]. Universities must take into account the relevance to apply sustainability practices aiming to enhance students' trust, empowering this way the institution's image.

Although co-creation has been studied previously by other scholars, they do not consider all these three variables simultaneously (participation, satisfaction, and trust). On the other hand, the contexts considered are also different, regarding both, region/country and field of studies. Co-creation for HESD in environmental engineering in Ecuador has not been studied to date.

Taking into account the main definitions of the variables involved, the hypotheses suggested for HE in this piece of research are:

- H1: Participation has a positive impact on co-creation.

- H2: Co-creation has a positive impact on satisfaction.

- H3: Co-creation has a positive impact on trust.

The following is a more detailed explanation of the theoretical background of these hypotheses.

\subsection{The Relationship between Participation and Co-Creation}

Co-creation is generated through student participation in creation, production, and delivery of services, enhancing collaboration between the HEI and the students [61,62]. This process allows for institutions to better understand student expectations [15,63] (apart from other stakeholders within $\mathrm{HEI}$ ). Moreover, communicative participation reduces the gap between student expectations and the final delivered services [64]. In this sense, it is important to highlight that in HEI, communication technologies have evolved considerably. There is a tendency to create communicative spaces, most of which are based on the internet, e.g., instant messaging. These actions strengthen communicative and collaborative activities [65], and, due to the variety and accessibility of channels [66], they have led to the development of co-creation [67] in this context.

Participation is one of the key elements of co-creation, with value co-produced by the collaboration of stakeholders, including students $[61,65,68,69]$. Some of the main requirements for successful co-creation are: "experience mindset, context of interactions for collective intelligence, engagement platform, and network relationships" [68] (p. 828). Therefore, to offer the best service, stakeholder partnership (including students) is imperative [70].

Participation is also explored in the HESD context, as [12] (p. 1) mention, becoming a request to achieve sustainable development in HEI, and it "contributes towards the integration of sustainability concept into the university culture." Hence, co-creation, co-design and co-production of sustainability in higher education is possible to achieve through the engagement of the stakeholders involved, and 
specially, students. As [71] (p. 3) reflect "students' involvement and participation translates into solving real-world sustainability problems".

It has been shown that students, as one of the key stakeholders in university processes, need to be empowered to implement successfully SD in HE [12]. Also, it has been identified some strategic fields to redirected the organizational change for HESD, been among them "institutional commitment, shared vision of the future, sustainability indicator reporting, participatory management structures and external partnerships" [72] (p. 700); consequently, the participatory approach constitutes a key element.

\subsection{The Relationship between Co-Creation and Trust}

It has been observed that student confidence is based on trust on the university staff and faculty, and on institution management, which includes policies and practices [24]. In this way, [73] (p. 334) analyses trust as "the extent to which students are confident about the efficacy of learning resources and are able to rely on both faculty and in particular fellow student generated content for their learning."

The link between co-creation and trust has been confirmed by authors like [74-77]. According to [70], the degree of involvement in co-creation prefigures the level of trust. The variables determining trust were ability, benevolence, integrity, and trust propensity; trust being related to factors such as the balance of power, risk perception, and the existence of alternatives [78].

Ref. [79] research has demonstrated that institutions with an approach based on co-creation achieve higher levels of loyalty and trust, with dialogue among the involved parties [80]. Ref. [81] in their study of HE institutions, also highlight that co-production involvement encourages elements, such as satisfaction, trust, commitment, and loyalty to the university. Furthermore, [82] remarks that student interaction in value creation increases student trust in the learning system.

\subsection{The Relationship between Co-Creation and Satisfaction}

Co-creation has been found to increase satisfaction [67,74,82-84] through the generation of emotional bounds, allowing for HE institutions to determine student expectations and to discover how to increase educational quality and student gratification [85].

Ref. [84] also highlighted the positive effect of co-creation on satisfaction, explaining this relationship in terms of how participation generated satisfaction during value creation. Ref. [23] also emphasized student co-creation in HE, where this collaboration is a key component in student experience, especially in their pursuit of their goals. They demonstrated that the positive relationship between co-creation and satisfaction, based on collaborative activities such as decision making. Likewise, ref. [17] reflected in his study on the transition from the student seen from a customer perspective, where the assessment of the experience quality is focused on the outcomes, to a student seen as a collaborator in knowledge co-production, in which the key element is to monitor the student's satisfaction.

In addition, Ref. [86] concludes that student involvement in the learning process has a positive impact in terms of "persistence, satisfaction, achievement and academic success" and suggests strategies to implement such a collaborative environment in terms of, for instance, the construction of a university community developing the sense of belonging, or fostering the use of ICT.

It should be noted that, previous studies, like [58], have analysed the positive relationship between students motivation-satisfaction and the learning outcomes in sustainability sciences. Considering these results, the link between satisfied students and their effective learning in sustainability issues is confirmed.

\section{Method}

The empirical study analyses data from Ecuadorian universities, and more specifically environmental engineering student. Firstly, 16 Ecuadorian universities were contacted in September 2014, with the aim of involving them in the research; however, only 12 institutions accepted to collaborate. Those universities were visited by the team of researchers, and the survey was handed-in 
in person to all of the available students, offering an online version to those who were not present at that moment. An introductory explanation of the survey and its purpose was made before the students completed it in order to clarify the main goal of the research and the questionnaire. As a result, 395 undergraduate students between the ages of 19 and 23 participated in the study. Table 1 shows the main characteristics and attributes of the respondents. The questionnaire used as a measuring tool was composed by 13-question. Table A1 collects the items for each measure. Ten different versions of the same questionnaire were provided, altering the order of the questions, in order to avoid possible bias. All of the questions were extracted from previously validated studies $[67,87]$. There were four questions for the co-creation variable, whereas the remaining three variables (participation, satisfaction, and trust) included three questions each. A Likert scale with 7-point scale (from (1) I strongly disagree, to (7) I completely agree) has been used as possible answers. The questionnaire was provided through two different channels, in person (handwritten) and virtually (Google document).

Table 1. Characteristics of Respondents and Universities Involved in the Study.

\begin{tabular}{ccc}
\hline Variable & $\begin{array}{c}\text { Number } \\
\text { Gender }\end{array}$ & Percentage \\
\hline Man & 303 & $76.7 \%$ \\
Woman & 92 & $23.3 \%$ \\
\hline \multicolumn{3}{c}{ Semester } \\
3rd & 84 & 21.3 \\
4th & 99 & 25.1 \\
5th & 27 & 6.8 \\
6th & 25 & 6.3 \\
7th & 81 & 20.5 \\
8th & 54 & 13.7 \\
9th & 25 & 6.3 \\
\hline & Modality & 30.8 \\
\hline Virtually (Google Form) & 122 & 69.2 \\
\hline & 273 & 83.3 \\
\hline Public & University Type \\
Private & 10 & 26.7 \\
\hline
\end{tabular}

As a first step, an exploratory factor analysis (EFA) was carried out to validate the instrument using SPSS. The extraction method used was the maximum likelihood with varimax rotation, setting four components (participation, co-creation, satisfaction, and trust). Then, as a second stage, a confirmatory factor analysis (CFA) with the programme SPSS Amos 19 was performed. In this step, the existing relationship between constructs and items was studied. To analyse the structural equation modelling (SEM), the SPSS Amos 19 programme was used. This was done to explore the modelling of the interactions among the constructs. Different indicators were tested to validate the model's fit.

\section{Results}

The AFE analysis detected two conflicting items, one related to trust and another one related to satisfaction. Therefore, these items were removed for subsequent analyses. After developing another EFA iteration without the conflicting items, an excellent Cronbach's alpha value was obtained $(0.926>0.7)$. Although the explained variance acquired was $66.53 \%$, the Kaiser-Meyer-Olkin (KMO) value was acceptable $(0.936>0.5)$ and the Bartlett test gave $p=0.000$. As a result of this first analysis, it was possible to determine that the applied instrument did, in fact, measure the variables of interest (co-creation, participation, satisfaction, and trust). 
Table 2 shows the key findings of the CFA; the composite reliability (CR) of the constructs produced excellent values, higher than 0.7. For the convergent validity, the average variance that was extracted (AVE) was higher than 0.5 for each construct. The maximum shared variance (MSV) and the average shared variance (ASV) were also determined in order to analyse the discriminant validity, with both values found to be less than or equal to the AVE. Also, another aspect considered was the square root of AVE, which was greater than the inter-construct correlations.

Table 2. Confirmatory Factor Analysis Results.

\begin{tabular}{lccccccc}
\hline & \multirow{2}{*}{ CR } & AVE & MSV & ASV & \multicolumn{2}{c}{ Correlations among the Constructs } \\
\cline { 7 - 8 } & & & & & Participation & Co-Creation & Satisfaction \\
\hline Participation & 0.766 & 0.523 & 0.389 & 0.330 & & & \\
Co-creation & 0.896 & 0.684 & 0.643 & 0.550 & 0.624 & & \\
Satisfaction & 0.838 & 0.721 & 0.674 & 0.546 & 0.566 & 0.802 & 0.821 \\
$\quad$ Trust & 0.805 & 0.674 & 0.674 & 0.524 & 0.530 & 0.785 & 0.53 \\
\hline
\end{tabular}

SEM results are presented in Figure 2. All of the indicators of model fit have good values: chi-square/degree of freedom ratio (CMIN/DF $=3.754<5$ acceptable), comparative fit index $(\mathrm{CFI}=0.958>0.95)$, goodness of fit index $(\mathrm{GFI}=0.956>0.95)$, adjusted goodness of fit index $($ AGFI $=0.892>0.80)$, standardised root-mean-square residual $($ SRMR $=0.079<0.08)$, and the root-mean-square error of approximation (RMSEA $=0.08 \leq 0.08$ ). The squared multiple correlation of satisfaction showed that $69.4 \%$ of this element is explained by the direct effect of co-creation; and, $73.1 \%$ of trust variance is explained by co-creation.

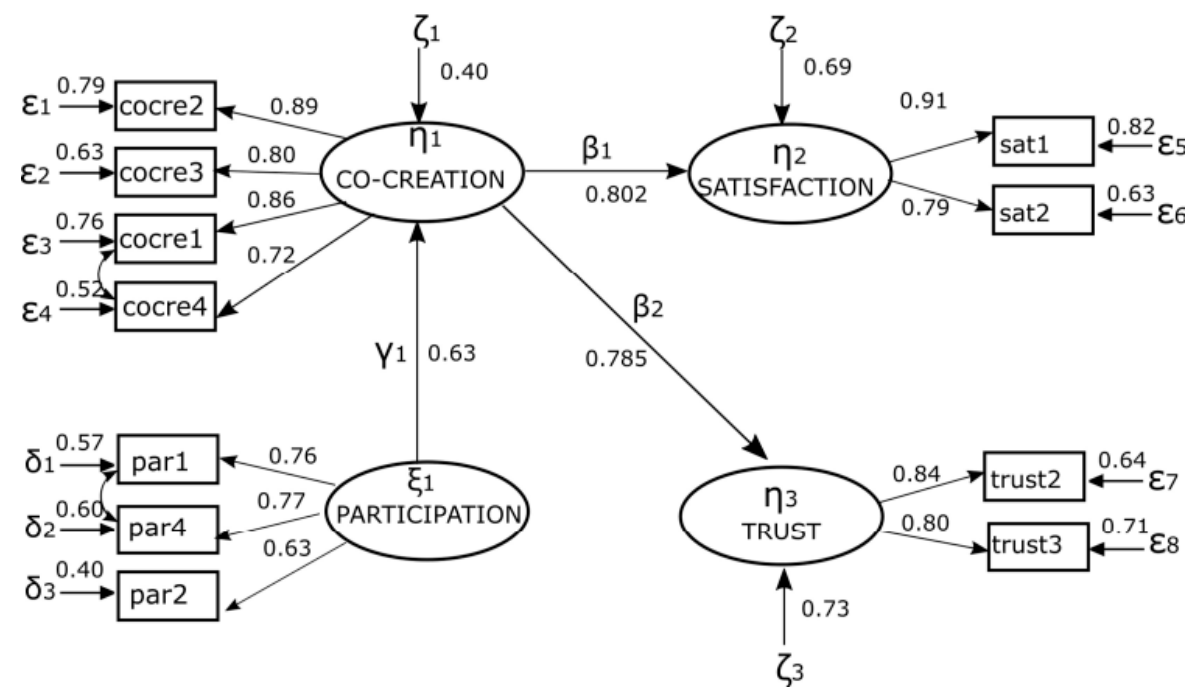

Figure 2. SEM results.

The three hypotheses of this study were shown to have a significant and positive impact. Participation has a positive impact on co-creation $(\gamma=0.63, p<0.001)$; co-creation has a positive impact on trust $(\beta=0.785, p$-value $<0.001)$. The highest impact refers to co-creation's impact on satisfaction $(\beta=0.802, p$-value $<0.001)$.

Until this point, we can state from an empirical perspective that student involvement has positive impact into co-creation, reinforcing the suitability to include co-creation as an alternative in environmental programmes. The ESD principles at these programmes are strengthened through this collaboration, and so is student behaviour as their trust and satisfaction are higher. 


\section{Discussion and Implications}

The impact of participation on co-creation has been demonstrated in the context of environmental engineering programmes in Ecuadorian Universities. In this particular case, it has been proved that applying strategies based on co-creation models is relevant to foster learning and teaching methodologies, particularly in an HESD context.

This study has validated our proposed model. Our findings encourage Higher Education institutions to implement value co-creation in order to increase students' satisfaction and future trust towards the institution, and, hence, improving the success of HESD programmes, at least in the context of environmental engineering. Furthermore, this piece of quantitative research also shows that participation has a positive influence in this value creation process.

This result have been demonstrated at universities in a developing country context, Ecuador. This is a specific context which had not been analysed in depth before.

When considering other context, the ties between co-creation and satisfaction have been confirmed previously by the work of authors such as $[65,80,81]$; on the other hand, the relationship between co-creation and trust has been already confirmed by the works of $[73,74]$, among others. Taking student voice into account and empowering them to participate in the different decisions and activities carried out at educational institutions, the co-creation approach helps to eliminate existing barriers between staff and student, and thereby to generate a climate of harmony where ESD is much more effective. In so doing, students not only develop skills, such as communication, autonomy, leadership, and teamwork-skills, which prepare them for the labour market, but they also enjoy greater satisfaction and confidence in their institutions. For those reasons, this study suggests that if Ecuadorian universities focus on HESD as a branch of the PNBV, students' involvement become crucial to this ambitious project.

When HE institutions successfully engage students in the design of courses/curricula and in the development/dissemination of knowledge as a part of the co-creation process, not only transversal skills of students, needed for future employability, are trained, but they also are developed and enhanced. In this way, students enhance their self-learning ability, performance, communication, and critical thinking skills (among others). They also take more responsibility for their own learning. Thanks to this collaboration, environmental engineering students become aware of what is learned, taking a collaborative role through dynamic activities, such as group work or debates. This interaction benefits not only students, but also faculty, obtaining a solid feedback loop thanks to this dynamic. The fact that students are offering their collaboration, their inclusion, their ideas, their effort, and their voice will contribute to enhance the success of HESD programmes.

The empowerment, which is given to students, strengthens the vision and commitment that they feel toward the educational institution. For that reason, strong bonds are generated, fostering feelings of satisfaction, and corresponding equally with trust and confidence toward decisions made about $\mathrm{HE}$ and their future.

Satisfied and confident students will not only benefit themselves, but they will also generate future comments, through word of mouth, that will benefit the institution. Those happy and harmonious students, as a result of the processes of which they were a part, will not only generate unpaid positive advertising, but also guarantee their future involvement in post graduate programmes or other activities carried out by the institution. The quality of university services will be reflected in those students' feelings, and this is the reason why co-creation constitutes a feasible strategy in order to obtain benefits to all parties involved, particularly to students.

The implementation of this open innovation perspective will enable universities to gain a higher share of the educational market, being able to strengthen in this way the HESD programmes. Co-creation may also allow for students to foster the skills needed to promote sustainable development, preparing them, in this way, as a better professional, useful to society.

It has been proved that value co-creation, with a solid student intervention and collaboration, allows students to achieve competences and skills necessary in the ESD context. Particularly, it is shown 
as a feasible solution to be applied in environmental engineering degrees at Ecuadorian universities, in order to develop a sustainable society.

All in all, the main contribution of this piece of research is two-fold. On the one hand, co-creation is suggested as a feasible perspective to reinforce the student's know how and capabilities relevant for sustainability. On the other, under an ESD perspective, this study also contributes to fill the research gap in a developing country, a context lacking research to date.

When considering that acquiring competencies is hardly comparable with learning as knowledge acquisition; competencies are described as learnable but not teachable [3], which is why ESD is built on an "open-minded and participative process" focused on the "development of knowledge, skills, perspectives and values related to sustainability" [3] (p. 416), demanding a change in the actual vision for education.

The competence-based education at ESD also fosters an innovative view, integrating "knowledge, skills, attitudes and values" with the relationship between student's competences and labour market need [88] (p. 777). Due to this fact, implementing SD (Sustainable Development) education demands a change of the traditional educational models, towards new ones focusing "on experiential learning, reflective learning, participative learning, active learning, creativity, collaboration, problem-solving, practice-based learning, transdisciplinary approach and self-regulation" [88] (p. 782).

Finally, our research proves to be a helpful tool that can help universities benefit from the potential of co-creation, enabling for them to develop a competitive strategy that will generate more value for their undergraduate environmental students, and which will also be difficult for the competition to copy, a point made by [89] in relation to developing differentiation strategies.

\section{Limitations and Further Research}

The main limitation of this research is that it was developed only in the Ecuadorian context. It is possible that the particularity of the cultural and geographical elements entail that the results may not be generalised at a global scale outside of this context. It would be interesting and useful in the future to develop similar cross-sectional studies in other environments to make comparisons, and to analyse whether the same student behaviour is maintained in terms of collaborative methodologies. The application of ESD in Ecuador is addressed in the present research filling an existing gap in the literature, but when considering the lack of studies in ESD in developing countries, it is necessary to replicate this kind of investigation in other Latin-American countries. Those future researches will help to detect differences and patterns in learning contexts when considering the ESD, contributing to reinforce this knowledge area.

Another research limitation is that the study includes students from environmental programmes only, which limited the sharing of the findings to other areas.

On the other hand, although there is a general awareness of co-creative practices at HESD, generating ideas and projects that allow for the auspicious implementation of this vision remains a challenge. Key areas for further improvement include the continued training of faculty, clearly delineated guidelines to effectively implement new approaches, and the creation of physical and virtual channels that connect students with the university. Given that the Ecuadorian system of HESD is currently developing actions to ensure quality in teaching and learning, along with quality in research and administrative activities [90], it will be useful to study the main process to modify and adapt them to a participative environment.

Acknowledgments: This research received no specific grant from any funding agency in the public, commercial, or not-for-profit sectors.

Author Contributions: All authors contributed equally to manuscript elaboration.

Conflicts of Interest: The authors declare no conflict of interest. 


\section{Appendix A}

Table A1. Questionnaire Applied in Measuring Co-creations, Participation, Satisfaction and Trust.

\begin{tabular}{|c|c|c|}
\hline Items & Questions & Factor Loadings (CFA) \\
\hline \multicolumn{3}{|c|}{ Participation (Extracted from [75]) } \\
\hline Par1: & $\begin{array}{l}\text { I put a lot of effort into expressing my personal needs to the staff during the } \\
\text { service process. }\end{array}$ & 0.76 \\
\hline Par2: & I always provide suggestions to the staff for improving the service outcome. & 0.64 \\
\hline Par4: & I am very much involved in deciding how services should be provided. & 0.77 \\
\hline \multicolumn{3}{|c|}{ Co-creation (Extracted from [55]) } \\
\hline Cocre1: & $\begin{array}{l}\text { Overall, I would describe my relationship with this university as involving a high } \\
\text { level of co-creation. }\end{array}$ & 0.90 \\
\hline Cocre2: & $\begin{array}{l}\text { The final purchase solution was arrived at mainly through a joint effort between } \\
\text { the university and myself. }\end{array}$ & 0.88 \\
\hline Cocre3: & $\begin{array}{c}\text { What I receive from this university is due to work jointly between the university } \\
\text { and students. }\end{array}$ & 0.79 \\
\hline Cocre4: & I contribute actively to the final solution in the educational service I receive. & 0.74 \\
\hline \multicolumn{3}{|c|}{ Satisfaction (Extracted from [55]) } \\
\hline Sat1: & Overall, I am pleased with the services offered by this university & 0.90 \\
\hline Sat2: & The service offered by my university meets my expectations. & 0.80 \\
\hline Sat3: & I think I did the right thing when I enrolled in this university. & \\
\hline \multicolumn{3}{|c|}{ Trust (Extracted from [55]) } \\
\hline Trust1: & In our relationship, my university can be counted to do what is right. & \\
\hline Trust2: & In our relationship, my university has high integrity. & 0.83 \\
\hline Trust3: & In our relationship, my university can be trusted at all times. & 0.81 \\
\hline
\end{tabular}

\section{References}

1. Barth, M.; Michelsen, G. Learning for change: An educational contribution to sustainability science. Sustain. Sci. 2013, 8, 103-119. [CrossRef]

2. Kolleck, N.; Jörgens, H.; Well, M. Levels of governance in policy innovation cycles in community education: The cases of education for sustainable development and climate change education. Sustainability 2017, 9, 1966. [CrossRef]

3. Barth, M.; Godemann, J.; Rieckmann, M.; Stoltenberg, U. Developing key competencies for sustainable development in higher education. Int. J. Sustain. High. Educ. 2007, 8, 416-430. [CrossRef]

4. Lozano, R.; Ceulemans, K.; Alonso-Almeida, M.; Huisingh, D.; Lozano, F.J.; Waas, T.; Lambrechts, W.; Lukman, R.; Hugé, J. A review of commitment and implementation of sustainable development in higher education: Results from a worldwide survey. J. Clean. Prod. 2015, 108, 1-18. [CrossRef]

5. Lambrechts, W. Possibilities and practices of competences for sustainable development in higher education. In Research and Innovation in Education for Sustainable Development; Environment and School Initiatives-ENSI, ZVR-Zahl: Vienna, Austria, 2016.

6. Lozano, R.; Lukman, R.; Lozano, F.J.; Huisingh, D.; Lambrechts, W. Declarations for sustainability in higher education: Becoming better leaders, through addressing the university system. J. Clean. Prod. 2013, 48, 10-19. [CrossRef]

7. UNESCO. Definition of Education for Sustainable Development. 2012. Available online: http://www. unescobkk.org/fr/education/esd-unit/definition-of-esd/ (accessed on 15 March 2017).

8. Makrakis, V.; Kostoulas-Makrakis, N. Bridging the qualitative-quantitative divide: Experiences from conducting a mixed methods evaluation in the RUCAS programme. Eval. Program Plan. 2016, 54, 144-151. [CrossRef] [PubMed]

9. Lozano, R.; Merrill, M.Y.; Sammalisto, K.; Ceulemans, K.; Lozano, F.J. Connecting competences and pedagogical approaches for sustainable development in higher education: A literature review and framework proposal. Sustainability 2017, 9, 1889. [CrossRef]

10. Wiek, A.; Withycombe, L.; Redman, C.L. Key competencies in sustainability: A reference framework for academic program development. Sustain. Sci. 2011, 6, 203-218. [CrossRef] 
11. Aznar Minguet, P.; Ull, M.; Piñero, A.; Martínez-Agut, M.P. La sostenibilidad en la formación universitaria: Desafíos y oportunidades. Educ. XX1 2014, 17. [CrossRef]

12. Disterheft, A.; Caeiro, S.; Azeiteiro, U.M.; Leal Filho, W. Sustainable universities-A study of critical success factors for participatory approaches. J. Clean. Prod. 2015, 106, 11-21. [CrossRef]

13. Lambrechts, W.; Mulà, I.; Ceulemans, K.; Molderez, I.; Gaeremynck, V. The integration of competences for sustainable development in higher education: An analysis of bachelor programs in management. J. Clean. Prod. 2013, 48, 65-73. [CrossRef]

14. Muñiz, A.M.; Schau, H.J. How to inspire value-laden collaborative consumer-generated content. Bus. Horiz. 2011, 54, 209-217. [CrossRef]

15. Ribes-Giner, G.; Perelló-Marín, M.R.; Pantoja Díaz, O. Revisión sistemática de literatura de las variables clave del proceso de co-creación en las instituciones de educación superior. Literature review of the key variables of the co-creation process in higher education institutions. TEC Empres. 2017, 11, 41-53. [CrossRef]

16. Adomßent, M.; Fischer, D.; Godemann, J.; Herzig, C.; Otte, I.; Rieckmann, M.; Timm, J. Emerging areas in research on higher education for sustainable development-management education, sustainable consumption and perspectives from Central and Eastern Europe. J. Clean. Prod. 2014, 62, 1-7. [CrossRef]

17. McCulloch, A. The student as co-producer: Learning from public administration about the student-university relationship. Stud. High. Educ. 2009, 34, 171-183. [CrossRef]

18. Kotze, T.G.; Du Plessis, P. Students as "co-producers" of education: A proposed model of student socialisation and participation at tertiary institutions. Qual. Assur. Educ. 2003, 11, 186-201. [CrossRef]

19. Angela Zambrano, C. Enfoque de la Educación Para el Desarrollo Sostenible en la Formación Docente en el Ecuador. 2015. Available online: https://dspace.ups.edu.ec/bitstream/123456789/ 11028/1/Enfoque\%20de\%20la\%20educacion\%20para\%20el\%20desarrollo\%20sostenible\%20en\%20la\% 20formacion\%20docente\%20en\%20el\%20Ecuador.pdf (accessed on 3 March 2017).

20. Salequzzaman, M.; Stocker, L. The context and prospects for environmental education and environmental careers in Bangladesh. Int. J. Sustain. High. Educ. 2001, 2, 104-127. [CrossRef]

21. Ribes-Giner, G.; Peralt, A. Modelling the Co-Creation between Students and Universities and Its Effects to Loyalty and Satisfaction. Modelling for Engineering and Human Behaviour; Universidad Politecnica de Valencia: Valencia, Spain, 2014.

22. Ribes-Giner, G.; Rillo, A.P. Structural equation modeling of co-creation and its influence on the student's satisfaction and loyalty towards university. J. Comput. Appl. Math. 2016, 291, 257-263. [CrossRef]

23. Maxwell-Stuart, R.; Taheri, B.; Paterson, A.S.; O'Gorman, K.; Jackson, W. Working together to increase student satisfaction: Exploring the effects of mode of study and fee status. Stud. High. Educ. 2016, 1-13. [CrossRef]

24. Carvalho, S.W.; de Oliveira Mota, M. The role of trust in creating value and student loyalty in relational exchanges between higher education institutions and their students. J. Mark. High. Educ. 2010, 20, 145-165. [CrossRef]

25. Pantoja Díaz, O.; Ribes-Giner, G.; Perello-Marin, M.R. The impact of cocreation on the student satisfaction: Analysis through structural equation modeling. Abstr. Appl. Anal. 2016. [CrossRef]

26. Ribes-Giner, G.; Perello-Marín, M.R.; Díaz, O.P. Co-creation impacts on student behavior. Procedia Soc. Behav. 2016, 228, 72-77. [CrossRef]

27. Kopnina, H.; Meijers, F. Education for sustainable development (ESD) exploring theoretical and practical challenges. Int. J. Sustain. High. Educ. 2014, 15, 188-207. [CrossRef]

28. Anson, C.M.; Bernold, L.E.; Crossland, C.; Spurlin, J.; McDermott, M.A.; Weiss, S. Empowerment to Learn in Engineering: Preparation for an Urgently-Needed Paradigm Shift. Glob. J. Eng. Educ. $2003,7$. Available online: http:/ / www.wiete.com.au/journals/GJEE/Publish/vol7no2/Anson.pdf (accessed on 5 March 2017).

29. Ramos, T.B.; Caeiro, S.; van Hoof, B.; Lozano, R.; Huisingh, D.; Ceulemans, K. Experiences from the implementation of sustainable development in higher education institutions: Environmental management for sustainable universities. J. Clean. Prod. 2015, 106, 3-10. [CrossRef]

30. Yuan, X.; Zuo, J. A critical assessment of the higher education for sustainable development from students' perspectives-A Chinese study. J. Clean. Prod. 2013, 48, 108-115. [CrossRef]

31. Albareda Tiana, S.; Albareda Tiana, S.; Alférez Villarreal, A.; Alférez Villarreal, A. A collaborative programme in sustainability and social responsibility. Int. J. Sustain. High. Educ. 2016, 17, 719-736. [CrossRef] 
32. United Nations Educational, Scientific and Cultural Organization (UNESCO); C.O. Bonn Declaration. UNESCO World Conference on Education for Sustainable Development. 2009. Available online: http: / / www.unesco.or.kr/upload/data_center/2009_ESD_BonnDeclaration_eng.pdf (accessed on 6 March 2017).

33. Müller-Christ, G.; Sterling, S.; van Dam-Mieras, R.; Adomßent, M.; Fischer, D.; Rieckmann, M. The role of campus, curriculum, and community in higher education for sustainable development-A conference report. J. Clean. Prod. 2014, 62, 134-137. [CrossRef]

34. Holm, T.; Vuorisalo, T.; Sammalisto, K. Integrated management systems for enhancing education for sustainable development in universities: A memetic approach. J. Clean. Prod. 2015, 106, 155-163. [CrossRef]

35. Milutinovic, S.; Nikolic, V. Rethinking higher education for sustainable development in Serbia: An assessment of Copernicus charter principles in current higher education practices. J. Clean. Prod. 2014, 62, 107-113. [CrossRef]

36. Thomas, I.; Thomas, I.; Depasquale, J.; Depasquale, J. Connecting curriculum, capabilities and careers. Int. J. Sustain. High. Educ. 2016, 17, 738-755. [CrossRef]

37. Vincent, S.; Focht, W. US higher education environmental program managers' perspectives on curriculum design and core competencies: Implications for sustainability as a guiding framework. Int. J. Sustain. High. Educ. 2009, 10, 164-183. [CrossRef]

38. McCormick, M.; Bielefeldt, A.R.; Swan, C.W.; Paterson, K.G. Assessing students' motivation to engage in sustainable engineering. Int. J. Sustain. High. Educ. 2015, 16, 136-154. [CrossRef]

39. Mulder, K.F.; Ferrer, D.; Segalas Coral, J.; Kordas, O.; Nikiforovich, E.; Pereverza, K. Motivating students and lecturers for education in sustainable development. Int. J. Sustain. High. Educ. 2015, 16, 385-401. [CrossRef]

40. Abdul-Wahab, S.A.; Abdulraheem, M.Y.; Hutchinson, M. The need for inclusion of environmental education in undergraduate engineering curricula. Int. J. Sustain. High. Educ. 2003, 4, 126-137. [CrossRef]

41. Senplades. Plan Nacional del Buen Vivir. 2009. Available online: http://www.planificacion.gob.ec/wpcontent/uploads/downloads/2012/07/Plan_Nacional_para_el_Buen_Vivir.pdf (accessed on 1 March 2017).

42. Consejo de Educación Superior. Guía Para la Presentación de Proyectos de Carreras de Nivel Técnico o Tecnológico Superior y Equivalente. 2015. Available online: http://www.ces.gob.ec/doc/guia\% 20presentacion\%20carreras\%20abril\%202015.pdf (accessed on 1 March 2017).

43. Rojas, J.E. Reforma universitaria en el Ecuador. Etapa de transición. Innov. Educ. 2011, 11, 59-67.

44. Robinson, C.; Taylor, C. Theorizing student voice: Values and perspectives. Improv. Sch. 2007, 10, 5-17. [CrossRef]

45. Gustafsson, A.; Kristensson, P.; Witell, L. Customer co-creation in service innovation: A matter of communication? J. Serv. Manag. 2012, 23, 311-327. [CrossRef]

46. Kristensson, P.; Matthing, J.; Johansson, N. Key strategies for the successful involvement of customers in the co-creation of new technology-based services. Int. J. Serv. Ind. Manag. 2008, 19, 474-491. [CrossRef]

47. Sanders, E.B.; Stappers, P.J. Co-creation and the new landscapes of design. CoDesign 2008, 4, 5-18. [CrossRef]

48. Payne, A.F.; Storbacka, K.; Frow, P. Managing the co-creation of value. J. Acad. Mark. Sci. 2008, 36, 83-96. [CrossRef]

49. Bovill, C.; Cook-Sather, A.; Felten, P. Students as co-creators of teaching approaches, course design, and curricula: Implications for academic developers. Int. J. Acad. Dev. 2011, 16, 133-145. [CrossRef]

50. Hattie, J. Visible Learning: A Synthesis of over 800 Meta-Analyses Relating to Achievement; Routledge: London, UK, 2008.

51. Auh, S.; Bell, S.J.; McLeod, C.S.; Shih, E. Co-production and customer loyalty in financial services. J. Retail. 2007, 83, 359-370. [CrossRef]

52. Yi, Y.; Gong, T. Customer value co-creation behavior: Scale development and validation. J. Bus. Res. 2013, 66, 1279-1284. [CrossRef]

53. Bettencourt, L.A.; Brown, S.W.; Sirianni, N.J. The secret to true service innovation. Bus. Horiz. 2013, 56, 13-22. [CrossRef]

54. Ramaswamy, V.; Gouillart, F. Building the co-creative enterprise. Harv. Bus. Rev. 2010, 88, 100-109. [PubMed]

55. Díaz-Méndez, M.; Gummesson, E. Value co-creation and university teaching quality: Consequences for the European Higher Education Area (EHEA). J. Serv. Manag. 2012, 23, 571-592. [CrossRef]

56. Nejati, M.; Nejati, M.; Shafaei, A. The influence of sustainability on students' perceived image and trust towards university. Int. J. Manag. Educ. 2015, 9, 411-425. [CrossRef]

57. Stauss, B.; Neuhaus, P. The qualitative satisfaction model. Int. J. Serv. Ind. Manag. 1997, 8, 236-249. [CrossRef] 
58. Azeiteiro, U.M.; Bacelar-Nicolau, P.; Caetano, F.J.; Caeiro, S. Education for sustainable development through e-learning in higher education: Experiences from Portugal. J. Clean. Prod. 2015, 106, 308-319. [CrossRef]

59. Randall, W.S.; Gravier, M.J.; Prybutok, V.R. Connection, trust, and commitment: Dimensions of co-creation? J. Strat. Mark. 2011, 19, 3-24. [CrossRef]

60. Baumann, J.; Le Meunier-FitzHugh, K. Trust as a facilitator of co-creation in customer-salesperson interaction-An imperative for the realization of episodic and relational value? AMS Rev. 2014, 4, 5-20. [CrossRef]

61. Shaw, G.; Bailey, A.; Williams, A. Aspects of service-dominant logic and its implications for tourism management: Examples from the hotel industry. Tour. Manag. 2011, 32, 207-214. [CrossRef]

62. Mulder, I.; Stappers, P.J. Co-creating in practice: Results and challenges. In Proceedings of the 2009 IEEE International Technology Management Conference (ICE), Leiden, The Netherlands, 22-24 June 2009; pp. 1-8.

63. Greer, C.R.; Lei, D. Collaborative innovation with customers: A review of the literature and suggestions for future research. Int. J. Manag. Rev. 2012, 14, 63-84. [CrossRef]

64. Rexfelt, O.; Almefelt, L.; Zackrisson, D.; Hallman, T.; Malmqvist, J.; Karlsson, M. A proposal for a structured approach for cross-company teamwork: A case study of involving the customer in service innovation. Res. Eng. Des. 2011, 22, 153-171. [CrossRef]

65. Timmis, S. Constant companions: Instant messaging conversations as sustainable supportive study structures amongst undergraduate peers. Comput. Educ. 2012, 59, 3-18. [CrossRef]

66. Devasirvatham, E.R. Modelling Co-Creation and Its Consequences: One Step Closer to Customer-Centric Marketing. Ph.D. Thesis, Auckland University of Technology, Auckland, The Netherlands, 2012.

67. Rajah, E.; Marshall, R.; Nam, I. Relationship Glue: Customers and Marketers Co-Creating a Purchase Experience. ACR N. Am. Adv. 2008. Available online: http:/ /acrwebsite.org/volumes/13297/volumes/v35/ NA-35 (accessed on 6 March 2017).

68. Lee, S.M.; Olson, D.L.; Trimi, S. Co-innovation: Convergenomics, collaboration, and co-creation for organizational values. Manag. Decis. 2012, 50, 817-831. [CrossRef]

69. Gruner, K.E.; Homburg, C. Does customer interaction enhance new product success? J. Bus. Res. 2000, 49, 1-14. [CrossRef]

70. Ordanini, A.; Pasini, P. Service co-production and value co-creation: The case for a service-oriented architecture (SOA). Eur. Manag. J. 2008, 26, 289-297. [CrossRef]

71. Kalamas Hedden, M.; Worthy, R.; Akins, E.; Slinger-Friedman, V.; Paul, R. Teaching sustainability using an active learning constructivist approach: Discipline-Specific case studies in higher education. Sustainability 2017, 9, 1320. [CrossRef]

72. Lambrechts, W.; Lambrechts, W.; Verhulst, E.; Verhulst, E.; Rymenams, S.; Rymenams, S. Professional development of sustainability competences in higher education: The role of empowerment. Int. J. Sustain. High. Educ. 2017, 18, 697-714. [CrossRef]

73. Wong, D.H. Reflections on student-university interactions for next generation learning. Asia Pac. J. Mark. Logis. 2012, 24, 328-342. [CrossRef]

74. Prahalad, C.K.; Ramaswamy, V. The Future of Competition: Co-Creating Unique Value with Customers; Harvard Business Press: Boston, MA, USA, 2004.

75. Terblanche, N.S. Some theoretical perspectives of co-creation and co-production of value by customers. Acta Commer. 2014, 14, 1-8. [CrossRef]

76. Dong, B.; Evans, K.R.; Zou, S. The effects of customer participation in co-created service recovery. J. Acad. Mark. Sci. 2008, 36, 123-137. [CrossRef]

77. Palmatier, R.W.; Scheer, L.K.; Evans, K.R.; Arnold, T.J. Achieving relationship marketing effectiveness in business-to-business exchanges. J. Acad. Mark. Sci. 2008, 36, 174-190. [CrossRef]

78. Mayer, R.C.; Davis, J.H.; Schoorman, F.D. An integrative model of organizational trust. Acad. Manag. Rev. 1995, 20, 709-734.

79. Malaviya, P.; Spargo, S. Relating to Customers: How and When to Strengthen Your Customers Relationships; Insead: Fontainebleau, France, 2002.

80. Selnes, F. Antecedents and consequences of trust and satisfaction in buyer-seller relationships. Eur. J. Mark. 1998, 32, 305-322. [CrossRef]

81. Bowden, J.L.H.; D'Alessandro, S. Co-creating value in higher education: The role of interactive classroom response technologies. Asia Soc. Sci. 2011. [CrossRef] 
82. Grönroos, C. Service logic revisited: Who creates value? And who co-creates? Eur. Bus. Rev. 2008, 20, 298-314. [CrossRef]

83. Bowonder, B.; Dambal, A.; Kumar, S.; Shirodkar, A. Innovation strategies for creating competitive advantage. Res. Technol. Manag. 2010, 53, 19-32. [CrossRef]

84. Grissemann, U.S.; Stokburger-Sauer, N.E. Customer co-creation of travel services: The role of company support and customer satisfaction with the co-creation performance. Tour. Manag. 2012, 33, 1483-1492. [CrossRef]

85. Ho, Y.C.; Shieh, H.M.; Yu, A.P. Effects of customer-value perception and anticipation on relationship quality and customer loyalty in medical tourism services industry. Inf. Technol. J. 2014, 13, 652-660.

86. Chan, K.W.; Yim, C.K.; Lam, S.S. Is customer participation in value creation a double-edged sword? Evidence from professional financial services across cultures. J. Mark. 2010, 74, 48-64. [CrossRef]

87. Krause, K. New Perspectives on Engaging First Year Students in Learning; Griffith Institute for Higher Education: Brisbane, Australian, 2007.

88. Lambrechts, W.; Lambrechts, W.; Van Petegem, P.; Van Petegem, P. The interrelations between competences for sustainable development and research competences. Int. J. Sustain. High. Educ. 2016, 17, 776-795. [CrossRef]

89. Cova, B.; Dalli, D.; Zwick, D. Critical perspectives on consumers' role as 'producers': Broadening the debate on value co-creation in marketing processes. Mark. Theory 2011, 11, 231-241. [CrossRef]

90. Pantoja Díaz, O.; González Rodríguez, M. Modeling and assessing the university community relations process: The Ecuadorian case. In Proceedings of the INTED 2014 8th International Technology, Education and Development Conference, Valencia, Spain, 10-12 March 2014; pp. 5407-5415.

(C) 2018 by the authors. Licensee MDPI, Basel, Switzerland. This article is an open access article distributed under the terms and conditions of the Creative Commons Attribution (CC BY) license (http:/ / creativecommons.org/licenses/by/4.0/). 